\title{
4
}

\section{Agrarian distress and gemstone mining in India: The political economy of survival}

\section{Arnab Roy Chowdhury and Kuntala Lahiri-Dutt}

\section{Approaching Kalahandi}

We reached the village Hinjlibahal in the Kalahandi district of Odisha ${ }^{1}$ and noted the grazing fields were dried and desiccated; parched surroundings familiar to the district. This is where even a casual visitor cannot help but notice the small pockmarks on the face of the land. These are remnants of holes that have been dug by villagers searching for gemstones. As they are left unfilled, they formed muddy puddles after the mild rains.

When questioned about the condition of these fields, a villager ${ }^{2}$ said, 'They were searching for ratna (gemstones)'. When asked about the people searching for gems, he said, 'Most of them are inhabitants from this village'. He also added that some time back, somebody from the village had a chance encounter with a very large piece of manik (ruby/ corundum ore) while tilling the paddy field. He said the person sold the gems for about INR20,000 (about US\$300) and was hiding somewhere. Apparently, the amount earned from selling the gem was sizeable, and

\footnotetext{
1 Formerly known as Orissa.

2 A Kulita farmer interviewed in Hinjlibahal on 12 June 2015. Kulita and Agariya are farming castes in this region.
} 
he had to go into hiding to avoid losing it or having to loan it to others. The news spread immediately, and many others began to dig their fields and the lands around the village.

We asked the villager what he did for a living. 'I am a "chasi" (peasant)', he said. 'Why don't you try your luck also?' we asked. When asked repeatedly, he said:

I do it sometimes to earn extra incomes but not always, I am old now, mining is unpredictable and dangerous ... Young people do it, sometimes for themselves or mostly working with the bigger chasis and gauntias ${ }^{3}$ in their fields. Most villagers are poor and live on a daily basis on meagre incomes. Smarter ones have left the village after earning some money. The rest spend the money as soon as it is earned, sometimes for innocuous and necessary causes such as to repay debt, buy family groceries, buying food etc. and sometimes on vices [he winked his eye] such as ... on modo (alcohol) and randis (prostitutes).

We asked another in the village whether he considered himself a peasant or a miner. This young Khond adivasi ${ }^{4}$ man, who works part-time as a speculative gemstone digger, mostly for himself, also owns a small piece of land for paddy cultivation, which provides subsistence for his family. Slightly irritated by our question, he proffered an almost philosophical discourse on mining.

We are also chasis, sometimes we dig for paddy and sometimes for stone. Mother Nature gives us paddy from the soil after we give our energy and sweat in it. We dig it and then sow the paddy, grow it with care, harvest it, husk it and process the paddy before we eat or sell it, we cannot eat paddy directly from the plant right? ... In the same manner, we dig and put our energy and sweat into the soil and Mother Nature bestows us with these gemstones, we wash them, cut them and polish them, and sell them, gemstones are like flowers of the soil, beautiful, variously coloured ... but we add value to them ... otherwise what value these stones have anyway?

We still live on our soil. Yes, mining is unpredictable. Sometimes, you find stones and sometimes you don't, but so is farming here, sometimes there is drought, no rain ... sometimes we have food and sometimes we don't. So what is the difference?

3 Traditional and erstwhile village headmen, the positional status is no longer valid; however, politically, socially, and economically they are still influential.

4 An umbrella term used to denote a heterogeneous group of tribes and indigenous group of people in India.

5 Between the peasant and a miner in this context, he implied. 
We were dumbstruck and did not have any suitable response to match his explanations, which drew an interesting simile between agriculture and mining. Indeed, he is absolutely right in pondering what ascribes value to gemstones. In a study on sapphire mining in Madagascar, Walsh (2010) wrote that it is an example of ultimate 'commodification of fetishes'. Various stories, narratives and geographic origin of stones add 'value' in a sense to mined sapphires (which are varieties of corundum), which otherwise can be easily produced in laboratories. But the international market value attached to naturally produced sapphire, termed as a 'work of god', cannot be produced in laboratories (ibid.: 111).

A substantial reserve of ruby weighing about 5,348 tonnes is located in the state of Odisha, mainly in Kalahandi and Nuapada districts (Das and Mohanty 2014: 1). It is one of the poorest, driest agricultural regions of eastern India. Starvation deaths and farmers' suicides, not its gemstone reserves, brought the region to global attention.

Although traditionally the Khonds knew the art of gemstone mining, they practised it during the non-farming, drier season between the $k h a r i f^{6}$ and the $r_{a b i}{ }^{7}$ crops after the rains stopped. The produce was brought to the Nagavamsi King families who ruled Kalahandi, and sold to the local landlords or zamindars. ${ }^{8}$ The seasonal activity was adopted to diversify their livelihood bases. Agriculture, particularly monsoon-fed paddy cultivation, remained the mainstay of economic life. Like other adivasis in this region who are subsistence farmers, peasants and landless labourers (Anonymous 1988), the terms adivasi and chasi conventionally represented their identity. As more villagers take up mining, their identity becomes complex, making it difficult to express through a single, generic term or profession. One question then arises: How do the villagers of Hinjlibahal like to represent themselves? We attempt to address this question in the conclusions.

We argue that agrarian distress and the frequent occurrences of drought for over a century initially led small peasants and labourers to practise artisanal mining, and allowed them to switch and shift between the two occupations seasonally. This occurred in the political-economic background of an extremely polarised and exploitative class structure,

6 Monsoon crop, that lasts from April to October.

7 Winter crop, sown in winter and harvested in spring.

8 In a similar vein, diamond washing has been traditionally done by Savara in Sambalpur and the Gonds and Kols in Madhya Pradesh (Biswas 1994: 401). 
traditionally advantageous to those with larger agricultural landholdings. We also show that since the liberalisation of the Indian economy in the 1990 s, opening up the region to foreign investments has brought in speculative and opportunistic traders from outside. Investments have connected the artisanal gemstone miners, as minute and insignificant labour, to a global market far beyond their comprehension. As national and international market chains generated interest and demands for gemstones, the adivasis and so-called 'lower caste' communities were assimilated into the 'value chain' primarily as labourers. The 'gem rush' of Kalahandi created more inequities than before.

\section{Mining by peasants}

Artisanal and small-scale mining (ASM) practices are informal modes of mineral extraction, mainly carried out by indigenous people, peasants and farmers globally (Hentschel et al. 2002). Artisanal mining covers relatively unorganised, clandestine, informal mining activities with a very low level of mechanisation mainly carried out by indigenous people and rural proletariats in common land or forest lands. Small-scale mining, on the other hand, is mechanised at a medium level, with organised and synchronised activities by a significant number of labourers, and generally controlled by a licensing authority. In our study region, gemstone mining includes scavenging, washing from alluvial deposits, digging in shallow trenches or inclines and surface mining such as quarries. It also includes small-scale mines such as unmechanised underground and surface mining.

In the absence of a clear definition of informal mining in India, production processes that involve manual methods such as panning and scavenging are considered 'artisanal'. In reality, a very large segment of all mining activities in India fit the definition of ASM (Deb et al. 2008). We define such mining as 'informal' to imply that it is part of the informal sector of the Indian economy. The characteristics of informal economy that Hart (1987) describes fit well with the informal mining economy. Smallsized production, low productivity, free entry and exit, labour-intensive production, activities determined by the casual labour market and the proliferation of self-employment are some characteristics of the informal economy and informal mining alike. 
It becomes necessary to notionally distinguish between legal, illegal and non-legal aspects of informal mining in India. In issues of community subsoil rights in the case of Panchayat Extension of Scheduled Areas Act 1996 (in the 5th and 6th schedules) of the state, it allows indigenous community ownership of mineral resources, such as artisanal coal mining in Meghalaya. Then there are 'illegal' artisanal mining cases on commons, state and private lands. However, scavenging gemstones from the banks of Mahanadi River near Hirakud Dam in Odisha or panning gold from the riverbank sand in Subarnarekha River in Jharkhand can be called non-legal or probably extra-legal, as no laws specifically criminalise these activities. Mining is mainly for livelihood purposes, but miners make very little money. Many miners live hand to mouth, and are extremely poor (Deb et al. 2008).

For some, artisanal mining is a continuation of their traditional livelihood. Others are thrown out of their community spaces by sudden economic and political changes of predatory globalisation, bolstered by large corporations in partnership with the state, causing large-scale displacement and forceful appropriation of land, water and forest resources of the poor through 'accumulation by dispossession' (Harvey 2004). Increasingly, large numbers of people in rural areas have lost their land, livelihood and cultural life-worlds due to a rise in land grab. They are pushed from traditional agricultural practices into the informal sector by global capitalist forces and designs. There is a surge in the number of development refugees (most of whom are erstwhile peasants) in informal mining in various parts of the developing world (Lahiri-Dutt 2007). Also, there is increasing tendency among the agriculturists to diversify through other temporary wage labour jobs, or even by leaving farming in favour of other jobs in rural areas, or migrating to the cities. This leads to what is known as deagrarianisation and de-peasantisation (Banchirigah and Hilson 2010).

Thus, poverty induced by factors over which the peasants and farmers have no control is one of the chief causes of the rural proletariat shifting to wage labour in mining. Banchirigah (2006: 165) explains how World Bank reforms in Africa led to rural impoverishment, and forced a large number of peasants into informal mining. The World Bank's International Roundtable on Artisanal Mining summary report, published in 1996, identified a link for the first time between rural impoverishment and growth of ASM. The roundtable delegates openly discussed that 'to a large extent informal mining is a poverty driven activity' (Barry 1996). The United 
Nations (UN) and the Department for International Development (DFID) have since publicised these ideas. Labonne (2003: 131), speaking on behalf of the United Nations Economic Commission for Africa, said, 'Because artisanal mining is largely driven by poverty, it has grown as an economic activity, complementing more traditional forms of rural subsistence earnings'. A Mining, Minerals, and Sustainable Development (MMSD) report observed that ASM activities in rural areas in many cases represent the most promising, if not the only, income opportunity available, and is often a strategy of diversifying the livelihood basket (MMSD 2002: 314). Banchirigah (2006: 166) argues that organisations that condemn the existence of ASM and poverty are also those responsible for it. In sub-Saharan Africa, policies pursued by the World Bank, International Monetary Fund and DFID have given rise to a dual mining economy. The large-scale mining industry is flourishing and is often monopolised by multinational corporate players. Conversely, the expansion of largescale mining, land acquisition, decreased land for peasant farming, loss of jobs, structural adjustment programs and privatisation of state enterprises has forced many into illegal ASM, operating in the interstitial spaces of capital - in conflict and in negotiation with it. In India, and in particular Kalahandi, initiating reform has a cascading malefic effect in forcing people to artisanal mining.

Bryceson (2002) argued that income diversification of most rural dwellers is for 'meeting daily needs amidst declining returns to commercial agriculture'. Many families have retained their base in subsistence farming and at the same time experimented with diverse non-farm livelihoods. These livelihood forms and choices are dependent on various agro-ecological, geographical and historical factors. Bryceson called this phenomenon a 'multiplex livelihood', and states that this diversification has, nevertheless, not produced a viable gainful employment, serious technical innovations, increase in purchasing power or improvements in forms of welfare. Citing Madulu (1998), she gave the example of Mwanza region of Tanzania where agrarian values run deep; however, the region has experienced a more recent boom in diamond and gold-mining. Eighty per cent of people involved in mining also farm in Mabuki village. When the farmers are asked who they think among their sons and daughters were 'successful' in life, in most cases they name those who are farmers. Here, pursuing farming and having large families are seen as markers of social status. 
Amidst increasing conflict between agriculture and mining is some literature that discusses 'mining-agriculture complementarity', whereby their coexistence generates socio-economic development. That is, on the one hand, mining competes with agriculture for land, water and labour, but pollutes agricultural water. On the other hand, mining generates income supplements for farmers to buy fertilisers or hire labourers and send their children for higher education (Hilson and Garforth 2012, 2013).

For example, the Bolivian Gold cooperatives workers have diversified their economy by combining agricultural activities with mining. This complementarity gives rise to a low degree of conflict and polarisation between agriculture and mining. This also suggests a relatively low mobility of mine workers where they are also attached to agriculture (McMahon et al. 1999).

Yeboah (2014) asserted there must be better understanding of the dynamics of mining and agriculture interaction. Understanding the nexus between the two is essential for producing healthy interaction so that mining does not jeopardise agriculture. However, the catch is that ASM is significantly more income-generating than agriculture, but it is less sustainable. Besides, large-scale mining generates significant 'externalities' such as pollution and displacement. Displaced farmers often try to regenerate their income from 'illegal' artisanal mining (Slack 2013). It is generally young farmers who choose ASM; farmers older than 50 usually avoid ASM because of its unsustainable nature (Yeboah 2014).

Despite its income-generating potential, Yeboah (2014) argued that mining cannot really replace agriculture; it is not an alternative economic activity, but is complementary. Citing the example of Ghana, Yeboah stated that many cocoa farmers and non-farming miners often get into conflicts due to claims of ownership over land that was customarily owned by farmers, without any documented rights. The local government usually intervenes to give these lands to non-farmer miners at low prices. Yeboah quoted one of the farmers who was interviewed-'These houses that you see were all built with cocoa money, this is what feeds us - and argued that farmers still have significant affinity for farming. 
In the case of Kalahandi, we find both sentiments in support of agriculture and mining present in the people, but differentiated along class lines. The poor who work as mine labourers still imagine themselves as farmers, and the rich send their children to higher education with this money. So, the complementarity only helps the rich in this case.

Therefore, it is necessary to understand that unregulated and unlicensed mineral extraction by syndicates on a massive scale must be differentiated from ASM for managing livelihood. It would be unfair to label the poor person with 'illegality of action', who somehow manages their life because of a lack of other choices (Bhanumathi 2003; Vagholikar et al. 2003).

However, official state policies or civil society often talk about formalising these spheres, thus regularising business production and supply chains. Siegel and Veiga (2009) use De Soto's theory of 'extra-legality' to explain informal mining. In the extra-legality framework, formalisation is a process of absorbing existing customary practices, developed informally by different communities into the mainstream of a country's legal and economic affairs.

However, there is a reverse current of logic that flows within the capitalist system as well, particularly in its neoliberal varieties, which casualises and informalises labour, and accumulates capital on the back of this cheap reserve pool of informal labour. In explaining the persistence of informality, Verbrugge (2015) argued that there are certain barriers and impediments to formalisation in informal mining. Some of them are certainly political and legalistic entry barriers; however, there is a complementary economic logic of mining pursued by vested interests. Referring to his own work, he illustrates that ASM in the Philippines can be seen as the 'product of a transition away from capital-intensive large-scale mining to a flexible regime of accumulation built around the exploitation of informal ASM labour' (ibid.: 1024). This is a new capitalist logic of flexible accumulation (Verbrugge 2015). To conceptualise it further, Tsing (2009), in a slightly different context, talked about the emergence of 'supply chain capitalism'. Supply chain capitalism occurs when large corporate houses accumulate capital and create value by colonising the commons and natural resources by integrating global supply chains. That way, informal production of commodities are connected to the more institutionalised channels and centres of capital. By doing this, capitalists reduce the overhead costs of employing a permanent workforce, create a wide continental crossing scale of supply chains and convert exploitation of environmental commons 
and natural resources as 'externalities' of the capital. This is the new model of capitalism that very aptly fits in understanding the coloured gemstone mining and production industry. This mode of integrating the informal chains of artisanal mining into global capitalist supply chains occurs throughout the world, and the Kalahandi gemstones are no exception.

Lahiri-Dutt (2014: 6) suggested that five major factors can be identified as operating at the confluence of the State and the Capital (with capitalised ' $S$ ' and ' $C$ ') that are pushing peasants out of agriculture to mining: state reform and attracting foreign direct investment; poor productivity of agriculture; the state trying to maximise revenue from mineral extractive industries following a development model that equates 'mining' with development; environmental degradation at regional and local levels due to various interlocked climactic patterns giving rise to the displacement and rise of numbers of 'environmental refugees'; and incentive to earn cash income to meet the rising price of commodities. All these lead to the social formation of 'extractive peasants', who were formerly peasants but are now engaged in various ASM activities for subsistence. Throughout Africa, Latin America and South Asia, this pattern is becoming increasingly obvious.

In Kalahandi, historical agricultural distress and low productivity was compounded by exploitative social structures that hindered social mobility. These play a huge role in setting the stage for farmers to practise artisanal mining in the initial phase. Later, that process was accelerated by the liberalisation of the economy after the 1990s, which attracted a vastly larger number of peasants to artisanal mining. The presence of gemstones in Kalahandi was little known to the outsiders; the region is a trove of many varieties of gemstone such as cat's eye (lahsunia), sapphire (pukhraaj/neelam), aquamarine (beruz), emerald (panna) and garnets (gomed). Historically, the place is called Karunda Mandal, or the abode of corundum ${ }^{9}$ (rubies). The important corundum- and ruby-bearing zones in Kalahandi are Jhillingdara, Hinjlibahal, Banjipadar and Kermunda. Kalahandi also produces some very good quality rubies. Most of these are eluvial and alluvial corundum that can be mined artisanally, and can be scavenged from the soil surface directly or by making small ditches (Das and Mohanty 2014: 1). The whole of western Odisha along the Mahanadi riverbank is historically known for its gemstone deposits and

9 Slightly low-quality rubies, which are often cut into cabochon shape and are sold as the 'Indian Star Ruby'. 
diamonds. ${ }^{10}$ The Sambalpur group of diamonds found in Mahanadi riverbanks, washed down from the lamprosite rocks of Madhya Pradesh, have been well recorded in history (Satapathy and Goswami 2006).

In ancient history, Kalahandi was ruled by the Nagavamsi rulers, whose family deity is aptly known as Manikeshwari (the goddess of rubies). Archaeological evidence from the nearby Asurgarh fort shows that these kings traded in gemstones. It is the Khond adivasis who used to mine, wash and polish the stones for the kings (Deo 1987).

Kalahandi district is surrounded by the districts Nuapada, Bolangir, Kandhamal, Rayagada, Koraput and Nawrangapur, and shares a part of the border with Raipur in Chhattisgarh (Mohanty 2010). The district was originally constituted by five zamindaris (landlords): Karlapat, Lanjigarh, Kashipur, Mahul-Patana and Madanpur-Rampur. Currently, the district comprises an area of $11,835 \mathrm{~km}^{2}$ (Pati 1999: 345).

Kalahandi has a high percentage of adivasis and scheduled caste population, at 28.65 and 17.67 per cent respectively. About 45 per cent of adivasis are Khond and the rest belong to the Gond and Savara tribes. The Khonds are mainly divided along two clan lines: the Dongariya and the Kathuria. The former mostly inhabit the hills and practise shifting cultivation, whereas the latter is involved in cultivating plains (Padel and Das 2010).

\title{
Agrarian distress in Kalahandi
}

\author{
Dalkhaire; \\ desare kala akala \\ Ghara duara chhadi bidese ghara \\ Dalkhaire peta kaje harabara.
}

(O leaf eater, drought occurred in the country and sent us abroad, beyond homeland, unrest for belly, O leaf eater) (Local folk song quoted in Mishra 2011: 5)

The popular fable in Kalahandi tells the story of Indra, the god of rain, who was once angry with the people of Kalahandi, punishing them by withholding rain for 12 years. This prolonged drought resulted in an unprecedented famine in the region: people and livestock died of starvation.

10 Artisanal mining of alluvial diamonds occurs in some places of India. In Africa, artisanal mining of diamonds from riverbeds employing divers is common (Van Bockstael and Vlassenroot 2008). 
The story then says that there was an old farmer, who summoned his sons, asking them to stop merrymaking now that he had become old like 'mature leaves of the dry tree' and might die soon. So he told them they must learn the technique of cultivation (Mishra 2011:3-4). So he took his sons and bullocks to till the field, but the earth was dry and quite difficult to penetrate. So he took his sons to the riverbed, which was sandy and relatively softer. They started ploughing the riverbed; this would give them an idea about how to plough the field in rainy season. Seeing the idiosyncrasy of these farmers, Indra descended from heaven in the guise of a Brahmin. He asked the old man why he was ploughing the riverbed. In response, the old man said that he knew it was futile to plough the sand at the riverbank, but he should not forget his occupation. According to him, 'parents must teach their descendants their parental occupation', in the hope of securing their future, 'otherwise where would they go and what would they do after their parents are gone'. This was an enlightening realisation for Indra. He returned to his home in heaven and ordered his four sons (four clouds) to learn how to precipitate rain on earth. Now the barren earth of Kalahandi was pouring with rain. The clever farmer thus emotionally roused the rain god and made him sympathetic to the people and extracted rain (Misha 2011).

The conditions of drought and famine in Kalahandi are a stark reality, a recurring historical event and leitmotif in the life and livelihood of Kalahandi farmers. Therefore, the story's traces and utterances abound, and are embedded in the mythical, cultural and social life of the people. However, famines and droughts are not merely 'events'; they are processes of slow emaciation, starvation, loss of energy and death of an entire community, and they have totally devastated the rural areas of Kalahandi slowly over the years (Mishra 2005).

Nevertheless, since 1985-paradoxically when the drought was relatively stabilised - the discourse of drought, famine and hunger entered national and international consciousness. It was in the 1990s that journalists started using the term 'Kalahandi syndrome' to depict periodic food shortages, decreasing income levels and starvation amidst plenty that continues here, despite significant and prolonged development interventions by the state and civil society. Kalahandi is not poor in resources. Outsiders flock here in huge numbers to tap its mining and forest resources; however, this does not contribute to any local development. 
Bouts of severe drought occurred in this region in 1866, 1868, 1884 and 1897. One of the most devastating droughts occurred in 1899 and in a way broke the backbone of the economy of this region (Mishra 2011). This famine, also known as Chhappan Salar Durbhikshya, affected people to such an extent that, even today, if a child cries for food, the mother says, 'why are you hankering like a drought-affected child of Chhappan sal?' (Mishra 2011: 2).

In the late colonial period from 1919 to 1920 , the drought was followed by diseases like cholera and influenza due to lack of food and resources. Drought occurred intermittently from 1922 to 1967, making threequarters of the crop fail, which created a reserve army of landless, unemployed agricultural workers. Finally, drought became relatively stabilised in the 1980s. However, it had devastating economic, political, psychological and corporeal consequences.

The landed class were the worst affected by the drought of later years. Due to social prestige of the class and status, they were not able to work as manual labour. Drought in a way created downward mobility of class rank and file; it pushed the classes such as rich peasants, middle peasants and other middle classes to lower positions. These categories of people turned into landless labourers in other's farmlands, colloquially called the Sukhbasis, meaning one who lives happily - the connotation is that one who has no possessions to worry about eventually lives happily (Mishra 2005, 2011). Each year, people have left the area en masse, permanently. Altogether, about 10,000 people, mostly from scheduled caste and tribe categories, have moved out of the Bolangir-Kalahandi area to Raipur in Chhattisgarh (Mishra 2011).

Despite droughts, famines and devastation, Kalahandi surprisingly is not rainfall poor. Data show that from 1977 to 1988, rainfall was about $1,255 \mathrm{~mm}$; by 1991 , this rose to $2,247 \mathrm{~mm}$. In this period, there was above average (than other districts of Odisha) production of food grains (Pradhan 1993: 1085).

This creates a conundrum for this region, the answer to which lies in its political, economic and social history. The drought that occurs in Kalahandi is not meteorological or agricultural drought. It is a situation of humaninduced drought and scarcity. The two main reasons behind this drought are poor management of the irrigation system and oppressive feudal social structures that created a polarised society—whereby landholding, and 
consequently economic and political power, lies with the upper class, who are also the upper caste. These issues are a deep chasm that polarise the society in such extremely unequal power poles, which disorientates and demoralises the oppressed.

Kalahandi is a paddy-cultivating region. Paddy is largely a waterdependent crop, so a large number of tanks, reservoirs, ponds and wells were constructed here for that purpose. The onus of maintaining these water bodies was with the local communities, and the gauntias (village heads) and the kings in the pre-colonial period.

With the advent of British colonialism, which introduced permanent settlement, a series of changes in land settlement and a set of new intermediaries were introduced in 1883, 1885 and finally in 1904-05 (Anonymous 1985). That created a drastic transformation in the land relations, social structure and power dynamics within and between various communities. This also permanently alienated the adivasis from their land and forest rights (Mishra and Rao 1992). Managing common resources were previously the responsibility of the rural feudal classes and communities. With the usurpation of 'common' land, water and forest bodies, managing them became nobody's duty. So the reservoirs, no longer managed by the older feudal nobilities and communities, became neglected and dilapidated structures.

In post-colonial times, this trend continued with improper water planning. This is compounded by the fact that Kalahandi has a spell of 'resource curse': rich in resources and hidden from the public eye under the shadow of a poor state like Odisha, outsiders and businessmen flock here for opportunities such as gem mining and trade (Pradhan 1993).

\section{Agrarian class structure in Kalahandi}

Kalahandi historically has a very exploitative rural class structure: on the one hand, the trade and business is controlled by urban outsiders, mostly Marwaris; on the other hand, the power in the agrarian class structure is monopolised by erstwhile gauntia (both Brahmin and non-Brahmin) and zamindar families. In Kalahandi, the gauntias or the village headmen are at the top of the rural class (and also caste) hierarchy (Sahu et al. 2004). 
Their power was initially bestowed by pre-colonial states for collecting revenue at the village level. This was later consolidated and legitimised by the colonial government through land revenue settlements. They usually controlled the best lands and also gained control over wastelands. They leased these lands on behalf of colonisers, and villagers who did not own any land were dependent on them. Slowly they started wielding immense power in the region (Sahu et al. 2014: 216).

Kalahandi was pre-colonially ruled by the Nagavamsi rulers, who brought in Brahmins ${ }^{11}$ and Kulitas from Sambalpur and Raipur region to Kalahandi. The Brahmins were mainly brought in to create a hegemonic state effect over the adivasi collective consciousness and bring them within the fold of Hinduism. Their presence ensured that the large transformation towards a peasantised and Hinduised caste and class-based hierarchical society emerged with a degree of social legitimacy. Striking consensus in an intense conflict-ridden field was to ensure maximised surplus production and tapping of resources in a peaceful process. The Kulitas were known to be hardworking and industrious farmers who could produce surplus grain and food for the population and revenue for the state. These people displaced most of the adivasis and the lower castes in the region (aided by the pre-colonial rulers and by the British colonisers) from their lands into marginal spaces (Pati 1999: 346).

The pre-colonial period saw a Brahmin, Kshatriya and Kulita alliance. Later, the colonial state legitimised this oppressive class structure and became the fourth and most powerful entity in this alliance. Hence, in the colonial period, increasing discrimination against the adivasis continued. In the process of dispossession, intense conflict occurred, such as the Kandha (same as Khond) rebellions of 1882, mostly directed against the colonial state and the Kulitas (Pati 1999: 347).

The oppressive agrarian rural structure and class base created a polarisation of land holdings, mostly owned by the erstwhile gauntias families and the rich Kulita and Agariya farmers, causing the poor peasants and tribes to become extremely indebted historically. Distress sale is a common phenomenon in Kalahandi that leads to enforced commercialisation of land, labour and crops. In the villages, the credit is informal and noninstitutionalised. The gauntias and the rich peasants, who were also the moneylenders, offered such credit. This kind of borrowing would lead

11 The ritually highest caste in the Indian caste hierarchy. 
to distress sale, where ' $\mathrm{t}]$ he crop in the field was usually purchased by the moneylender himself during harvest time at a nominal rate and the price was adjusted against loan including the interest on the credit' (Government of Orissa 1980, cited in Sahu et al. 2004: 216).

Kalahandi was merged with Orissa on 1 January 1948. However, the gauntia system and its exploitative structure remained. When this was finally abolished in 1956, they had reconfigured, restructured and consolidated their power in the villages. Their power remained intact in post-colonial Orissa, in the scenario of limited possibility of land reform (Pati 1999: 355).

After independence, the Orissa congress government tried to improve the position of these small holders (ryots) - who did not hold any title to the land, and were vulnerable to moneylenders-through protective legislations. However, it failed to create much change in the rural society (Sahu et al. 2004: 215-16). ${ }^{12}$

Extreme cases of distress have led to a population of farm labourers steeped in loans and mortgages. Given a chance, people would migrate easily to other adjoining states, with non-tribals being the first to migrate. The tribes are too attached to their lands; they also migrate, but mostly in extreme situations (Banik 1998). Poverty, debt and scarcity lead to starvation, death and suicides of farmers in significant numbers. From 2009 to 2015, a sizeable number of farmers took their lives (Dharitri 2009, 2015).

Relief is a usual thing that comes to salvage the drought and faminestricken. Through relief, the state reinforces its paternalistic responsibilities. The state purportedly provides relief of some kind, with the hope that it would trickle down to the poor, even when it is siphoned off in the middle through various channels of corruption. A number of nongovernment organisations have emerged in this process. In addition, there is a politics of relief that ensures by the time it is undertaken or the materials reach the community, its back is already broken and it is disempowered, which is visible in their destitution and starvation. The local people jokingly call the drought relief measures the teesra fasal (the 'third crop') (Sainath 1996).

12 Even in 1976, bonded labour existed in Kalahandi (Sahu et al. 2004: 216). 
Kalahandi is in the central location of the geography of hunger in western Odisha. By the time drought relief is available, already a 'complex progression of coping mechanism' and strategies are enacted. The Dongariya Khond face acute food shortages for about three to five months a year, mainly from May to June in the post-sowing monsoon period, and again in March by the time the kharif crop is already exhausted (Mohapatra 2012: 57). During this period, they eat dried, powdered and detoxified mango seed kernels, make a gruel with millet called mandia and consume liquor derived from the mowha (Madhuka longifolia) flower collected from the forest (Pati 1999: 348). They also consume berries, mushrooms, tubers, leaves and tamarind, mainly from the forest. The forest base is also shrinking due to depletion from large-scale, aggressive mining activities in Niyamgiri. Many families go into debt because of loans incurred to buy food (Mohapatra 2012: 57).

\section{The post-reform gem 'rush' in Kalahandi}

After liberalisation in 1991 and the consequent economic boom, the gems and jewellery industry rapidly grew in India due to demand from outside. From 1993 to 1998, the Odisha branch of the Geological Survey of India carried out a high-resolution airborne survey in collaboration with World Geoscience Corporation of Perth, Australia. This survey generated data for more than 330,000 line kilometres covering an area of 75,000 km $\mathrm{km}^{2}$ in hard rock terrain of the state (Directorate of Geology n.d.). It identified gem resources and 'mother lodes' - the main area of concentration of gemstone ores in western Odisha. The survey was done to identify and tap the main gemstone-rich areas through capitalised and mechanised mining. This rumour circulated within the gem and production industry, and huge interest grew in western Odisha. Gems had always been produced locally at a limited scale until then, mostly controlled by the class and caste elites for regional markets. The stones were mined by indigenous tribes and other so-called scheduled caste labourers. Speculative investors, businessmen, brokers and agents arriving in this region after the 1990s sparked a gem rush. Many people, irrespective of caste and class, started coming into the business to make the most of the emerging opportunities, using their existing traditional knowledge of gem production (Roy Chowdhury and Lahiri-Dutt 2016). 
They came with different levels of investment of capital and knowledge, in different capacities, to participate in the trade. Before the gem rush, tribal people were digging for the caste and class elites, mostly in off seasons at a relatively restricted and limited production scale. With the gem rush, the Khonds, other adivasis and other marginalised and so-called lower castes started digging for themselves individually and in groups, and also sometimes for illegal syndicates. Some also formed smaller groups of three to four people working as independent entrepreneurs; many of these groups have started working full-time in artisanal mining (Roy Chowdhury and Lahiri-Dutt 2016).

The increasing interest in mining was also in a way the last straw that poor, marginalised people could have grabbed at, against failing agriculture and economies of transition. That was the only option left for many of them before they would have migrated out of the region temporarily or permanently. In a way, agrarian distress, together with the reform, pushed and pulled a significant number of erstwhile marginal rural proletariat into artisanal mining. It became an activity in which they became doubly vulnerable to exploitation of various kinds — on one hand by the traditional elites and, on the other hand, by large corporations who pushed them out from their lands (Roy Chowdhury and Lahiri-Dutt 2016).

This area has recently started attracting many large corporate interests. A Special Economic Zone (SEZ) for gems and jewellery manufacturing is planned to be opened in the area by the Geetanjali group, one of the oldest companies in this industry. Chhattisgarh Futuristic Infrastructure Development Company has also proposed to open an SEZ for gems and jewellery manufacturing in Bhubaneswar, covering 150-200-acre lands with an initial investment of about US\$45 million. Additionally, the Oriental Timex company has acquired mining rights for black granite in the Malkangiri district of western Odisha. Multilateral development organisations such as the United Nations Development Programme have assisted the Odisha Government in setting up a semi-mechanised panning and screening facility, with mobile washing plants on the banks of the Mahanadi River (Government of Orissa 2009). Around 1991, the state of Odisha established a gem-testing laboratory in the Directorate of Geology under the guidance of the United Nations, which tests various kinds of stones at a very cheap rate (Biswas 1994). 
The Government of Odisha's Department of Steel and Mines is planning a survey of $80,707 \mathrm{~km}^{2}$ in northwest and central Odisha to find traces of coal, gold and gemstones. It has sought the assistance of the Odisha branch of the Geological Survey of India (GSI). They are also planning to survey the Kalahandi district for gemstones. Somewhat related to these mineral explorations, the state is also planning to draft a state-specific policy on SEZs, corporate social responsibility and industrial policy resolution. A total amount of approximately US $\$ 1.7$ million has been allocated for this survey (Business Standard 2014). The Odisha branch of GSI revealed that they have found significant gemstone deposits of topaz, tourmaline, agate and minerals like gold in the Boudh-Ramgarh area, along the Mahanadi and Tel riverbeds (Sahoo 2014). Through plans and programs, the state is aiming to extend and consolidate its extractive terrains in collaboration with capitalist firms. However, the global coloured gemstone production economy is slightly different from other mineral sources or even the diamond economy.

It is necessary to understand the process of mining rough stones and the social life that gems acquire after processing. After gems are mined, they pass through a chain of miners, brokers and wholesalers before being cut, polished and sold to the retail market. Many people in the coloured gemstone industry operate in the informal market, and are therefore difficult to track down. In contrast to diamonds, coloured gemstones are produced from relatively small, low-cost operations with a few dominant monopolisers in the market. Artisanal mining accounts for about 80-90 per cent of gemstone production (Cross et al. 2010).

The extremely fragmented nature of the gemstone market at every value chain makes it very difficult to identify significant actors. The global trade of coloured gemstones was roughly US $\$ 4$ billion in 2008 . Trade analysts say that this market has grown considerably since 2003. Most deposits of coloured gemstones are low yielding, and therefore mainly mined and produced through artisanal methods. The non-diamond coloured gemstone industries are cyclical and register a high point of production when a deposit is discovered, then go to a low point when it is exhausted. Different countries have emerged as prominent locations of coloured gemstone markets: Brazil in the 1950s and 1960s, Tanzania in the 1970s, and Afghanistan in the 1980s (Cross et al.: 17). This current phase will likely open up a high production point of coloured gemstones in the history of western Odisha. 
Officially, 605 mining leases have been sanctioned in Odisha, of which only 16 to 21 are for precious and semi-precious gemstones (Murthy and Giri Rao 2006). Among these, 13 legally leased gemstone mines are situated in Kalahandi (Government of Orissa 2009). But official gem mines are scarce in Odisha, so the main sources of gems are mined artisanally.

The mining pits are mostly dug in agricultural lands. Mining pit owners are usually rich farmers-mostly Kulita, Agariya or Mali ${ }^{13}$ by caste. Many pits are also owned by Brahmin gauntias. Most mining activities are carried out clandestinely in pits hidden in the agricultural fields. ${ }^{14}$

Most of the adivasis and the so-called scheduled caste miners, who do not hold any land, work in artisanal mining as wage labourers employed by pit owners to dig. Their chore is the same as agricultural labourers tilling fields, but they earn a little more in wages (Roy Chowdhury and LahiriDutt 2016).

Some pits are also dug in jungles, inaccessible mountain areas and common lands by individuals, loosely organised groups or highly organised syndicates. The syndicates also employ the adivasis and the lower-caste population as wage labourers in the mine. They operate at night in relatively difficult areas of the forest, clandestinely hiding their activities from forest officials and the police. ${ }^{15}$ Women's participation focuses on washing stones and sorting uncut pieces. Most labourers live hand to mouth, eating pakhala (fermented rice soaked in water) in good seasons and mandia in lean seasons. They are relatively better paid than the farm labourers. But their job is also risky in terms of health, life and legal issues involved. ${ }^{16}$

The process of mining is very rudimentary and primitive, using shovels and pickaxes. Because of the bluntness of these heavy instruments, sometimes stones get cracked internally and good-quality stones are not always produced (Roy Chowdhury and Lahiri-Dutt 2016). Pits are usually dug vertically like wells, about $1-3 \mathrm{~m}$ deep. Sometimes the pits are dug horizontally over a large area, as miners find good caches this way. Sometimes, small holes are carved in pit walls horizontally, just enough

13 Caste of gardeners.

14 Interview with a Khond local opinion leader in Thuamul Rampur, 14 July 2015.

15 Interview with a policeman in Bhawanipatna, Kalahandi, 1 July 2015.

16 Interview with a Khond miner in Kesinga, Kalahandi, 14 June 2015. 
to crawl into, for a person to work inside. These pits are generally built without any reinforcements, and they often collapse after rains. Accidents and deaths of miners are common in these pits. But people take these risks for daily subsistence money and in hopes of getting lucky.

Sometimes people do get lucky. A Kulita man from Kalahandi, now staying in Sambalpur, narrated how in 1994 his father, while crossing the Tel River on a boat, found something shining underneath the water in the shallow, sandy riverbank. He descended into this knee-deep water and picked up the piece. It was a large chunk of diamond. Later, he sold the stone to a Marwari businessman in Sambalpur, who paid him INR1million (about US\$17,000). His father invested the money in building a house in Sambalpur. They currently live there and he has started his own gem business. ${ }^{17}$ There are several rags-to-riches stories in Kalahandi. Many rich peasants and erstwhile gauntias send their sons and daughters to be educated in the most elite institutes in India or abroad under their own sponsorship.

Various kinds of stones are produced from these mines—ruby, corundum, aquamarine, cat's eye, sapphires (mostly white and yellow) and many other semi-precious stones. Alexandrite ${ }^{18}$ mining is also being pursued in Tel River valley near the Kalahandi-Chhattisgarh border (Sahu 2013).

These stones are usually bought at a wholesale rate from the mines by middlemen employed by bigger businessmen, who mostly come from Rajasthan and operate their base from the adjoining Katabanji in Bolangir (Banerjee 1993). These stones gain a social and economic life of their own. They are sorted and go through a process of cleaving (giving an initial cut or shape), calibrating, cutting and bruiting (polishing) mostly on the local or regional lapidary. The best stones travel through Raipur and Jharkhand, and usually end up in Rajasthan's international gem market. Here, stones are further cut and sorted, and sold directly from the retailer, either loose or more usually embedded in jewellery produced there or exported outside the country. ${ }^{19}$

17 Interview with a gem shop owner in Sambalpur on 20 June 2015.

18 First discovered April 1834 in Russia, it is named after the Czar Alexander II. It demonstrates a property of dual colour under different wavelengths of light (see www.gemstone.org/index. php?option=com_content\&view=article\&id=127:sapphire\&catid=1:gem-by-gem\&Itemid=14).

19 Discussion with Jamal (name changed), the key informant in Sambalpur, on 20 May 2015. 
As the businesses at the local level are mostly run by the caste and class elites, they have some degree of power, legitimacy and control over the local administration, which mostly act as docile and silent observers, for which they are paid. The local politicians also get a share of the trade, often given to them during elections. People stay docile; whoever tries to raise a voice is intimidated and 'taken care of' (Banerjee 1993).

\section{Conclusion}

Historically, Kalahandi's gemstone deposits have been artisanally mined by the Khonds, other adivasi and so-called low-caste labourers who mostly work seasonally for the feudal class of people such as gauntias, zamindars and the kings, and later in the fields of rich Kulita farmers. In conditions of severe drought and agrarian distress, this form of diversification of income was a survival strategy. Drought was so severe that it pushed many farmers out of the state to seek employment. But after the 1990s, there was a rediscovery of gem mining through interests initiated by economic reforms and resources in this region. In a pre-existing scenario of agrarian distress and knowledge of gemstone mining and production, there began and increase in demand and corporate interest, and opportunistic tradesmen and businessmen from outside the state. The anarchic opportunistic moment of gem rush absorbed both the poor and the elites to the extractive geography of gemstones in Kalahandi. In this process, the caste and class elites, and the merchant outsiders accumulated most of the capital by exploiting the informal labour of the adivasis. The marginalised and the vulnerable, in turn, were self-exploited for a slightly better life and relatively higher wages, as a survival strategy against extremely rapid economic, political and social transitions. Agriculture is still undertaken here along with mining, but this complementarity only helps the caste and class elites who are large landholders and who mine their land as well as use it for agriculture.

Revisiting the question briefly that we raised before: How do the villagers of Hinjlibahal like to represent themselves? Their identity is internally fractured now. They always practised cultivation, whether in the valley or in the hills. Mining was a lean season activity that supplemented cropping. They were always proud to be identified as a chasi or a peasant. Now, on the one hand agriculture is in distress, and on the other there is the anticipation of reform, and slow reform itself, in mining. These issues 
are pushing and pulling them out of their traditional occupation. These political and economic transformations are changing their life-world, and affecting the internal psychological world they are grappling with. They are part of the gem-mining labour process, but face an identity crisis and disenchantment collectively, due to the level of greed and fragmentation it produces socially. So they cling to their peasant identity that gave them a sense of honour, and are rationalising, renegotiating and trying to make sense of their transforming world.

As Banchirigah (2006) has shown in sub-Saharan Africa, economic reform fuelled an artisanal mining rush because it induced poverty. So, policies that are created for growth in the name of the poor itself tend to pauperise them. However, economic reform can trigger different societal responses, and the processes of pauperisation might take different routes in various contexts - as in the case of Kalahandi, reform of mining is at the same time pushing and pulling peasants into artisanal mining.

However, this is just the beginning. Corporatisation and land grabbing for gem mining has not yet been significant in Kalahandi. This is a transitional phase, as this space probably would soon be taken over by multinational gem mining and manufacturing houses for the creation of SEZs. As of now, companies are slowly moving in to colonise this space. The local elites and businessmen would probably adapt to these shifting political and economic situations in their own ways. The accumulation of capital would probably then be continued by companies by exploiting the adivasis as labourers. However, gemstones are finite resources, exhausted within a very short time; therefore, sustaining a life on this basis would remain as unpredictable and precarious as ever for these marginalised labourers.

\section{References}

Anonymous, 1985. 'Drought and Poverty: A Report from Kalahandi Orissa.' Economic and Political Weekly 20(44): 1857-60.

Anonymous, 1988. 'Kalahandi: A Stark Picture.' Economic and Political Weekly 23(18): 886-8. 
Banchirigah, S.M., 2006. 'How Have Reforms Fuelled the Expansion of Artisanal Mining? Evidence from Sub-Saharan Africa.' Resources Policy 31(3): 165-71. doi.org/10.1016/j.resourpol.2006.12.001

Banchirigah, S.M. and G. Hilson, 2010. 'De-agrarianization, Re-agrarianization and Local Economic Development: Re-orientating Livelihoods in African Artisanal Mining Communities.' Policy Science 43: 157-80. doi.org/10.1007/s11077-009-9091-5

Banerjee, R., 1993. 'Orissa: Discovery of Rich Deposits of Precious Stones Lures Villagers Towards Illegal Mining.' India Today, 15 November. Available at indiatoday.intoday.in/story/orissa-discoveryof-rich-deposits-of-precious-stones-lures-villagers-towards-illegalmining/1/303345.html

Banik, D., 1998. 'India's Freedom from Famine: The Case of Kalahandi.' Contemporary South Asia 7(3): 265-81. doi. org/10.1080/09584939808719844

Barry, M. (ed.), 1996. 'Regularizing Informal Mining: A Summary of the Proceedings of the International Roundtable on Artisanal Mining.' Industry and Energy Department Occasional Paper No. 6. Washington DC: World Bank, pp. 17-19.

Bhanumathi, K., 2003. 'Labour and Women in Mining.' Background paper presented at the Mines, Minerals and People for the Indian Women and Mining seminar, Delhi, April. Available at www.mines andcommunities.org/article.php? $\mathrm{a}=858$

Biswas, A.K., 1994. 'Gem Minerals in Pre-modern India.' Indian Journal of History of Science 29(3): 389-420.

Bryceson, D.F., 2002. 'Multiplex Livelihoods in Rural Africa: Recasting the Terms and Conditions of Gainful Employment.' The Journal of Modern African Studies 40(1): 1-28. doi.org/10.1017/ S0022278X01003792

Business Standard, 2014. 'Odisha to Survey in 80,707 sq km Area for Traces of Gold, Coal, Gemstone.' Business Standard, 27 July. Available at wap.business-standard.com/article/economy-policy/odisha -to-survey-in-80-707-sq-km-area-for-traces-of-gold-coal-gemston e-114072700737_1.html 
Cross, J., S. van der Wal and E. de Haan, 2010. 'Rough Cut: Sustainability Issues in the Coloured Gemstone Industries.' Amsterdam: Centre for Research on Multinational Corporations (SOMO).

Das, S.K. and J.K. Mohanty, 2014. 'Characterisation of Eluvial Corundum (Ruby) from Kermunda, Kalahandi District, Odisha, India.' Journal of Geology and Geosciences 3: 180.

Deb, M., G. Tiwari and K. Lahiri-Dutt, 2008. 'Artisanal and Small-Scale Mining in India: Selected Studies and an Overview of the Issues.' International Journal of Mining, Reclamation and Environment 22(3): 194-209. doi.org/10.1080/17480930701679574

Deo, P.K., 1987. 'Why Kalahandi is called Karond or Kharonde?' The Orissa Historical Research Journal 31: 9-14.

Dharitri, 2009. 'Farmer Suicide in Kalahandi District of Western Odisha.' 18 November.

Dharitri, 2015. 'Farmer Attempts Suicide in Kalahandi.' 5 March.

Directorate of Geology, n.d. Available at orissaminerals.gov.in/Geology/ Default.aspx

Government of Orissa, 2009. Compendium of Mineral Resources of Orissa. Department of Steel and Mines, Government of Orissa.

Hart, K.J., 1987. 'Informal economy.' In J. Eatwell, M. Milgate and P. Newman (eds), The New Palgrave Dictionary of Economics. London: Palgrave MacMillan. doi.org/10.1057/978-1-349-95121-5_804-1

Harvey, D., 2004. "The "New" Imperialism: Accumulation by Dispossession.' Socialist Register 40: 63-87.

Hentschel, T., F. Hruschka and M. Priester, 2002. Global Report on Artisanal \& Small-Scale Mining. Minerals Mining and Sustainable Development, no. 70. International Institute for Environment and Development, World Business Council for Sustainable Development.

Hilson, G. and C. Garforth, 2012. "Agricultural Poverty" and the Expansion of Artisanal Mining in Sub-Saharan Africa: Experiences from Southwest Mali and Southeast Ghana.' Population Resources Policy Review 31(3): 435-64. doi.org/10.1007/s11113-012-9229-6 
Hilson, G. and C.J. Garforth, 2013. "'Everyone Now is Concentrating on the Mining": Drivers and Implications of Changing Agrarian Patterns in the Eastern Region of Ghana.' The Journal of Development Studies 49(3): 348-62.

Labonne, B., 2003. 'Seminar on Artisanal and Small-Scale Mining in Africa: Identifying Best Practices and Building the Sustainable Livelihoods of Communities.' In G. Hilson (ed.), The Socioeconomic Impacts of Artisanal and Small-Scale Mining in Developing Countries. The Netherlands: A.A. Balkema. doi.org/10.1201/9780203971284. ch9

Lahiri-Dutt, K., 2007. 'Illegal Coal Mining in Eastern India: Rethinking Legitimacy and Limits of Justice.' Economic and Political Weekly 42(49): 57-67.

Lahiri-Dutt, K., 2014. 'Extracting Peasants from the Field: Rushing for a Livelihood?' Working Paper Series No. 216. Asia Research Institute, National University of Singapore.

Madulu, N.F., 1998. 'Changing Lifestyles in Farming Societies of Sukumaland: Kwimba District, Tanzania.' Working Paper No. 27. Dar es Salaam: Institute of Resource Assessment, and Leiden: African Studies Centre.

McMahon, G., J.L. Evia, A. Pascó-Font and J. Miguel Sánchez, 1999. 'An Environmental Study of Artisanal, Small, and Medium Mining in Bolivia, Chile, and Peru.' World Bank Technical Paper No. 429. Washington DC: The Word Bank.

Mining, Minerals and Sustainable Development (MMSD), 2002. Breaking New Ground. London: Earthscan Publications.

Mishra, A., 2005. 'Local Perceptions of Famine: Study of a Village in Orissa.' Economic and Political Weekly 40(6): 572-8.

Mishra, M.K., 2011. Kalahandi Drought Lore. Solo, Central Java, Indonesia: Centre for River Basin Organizations and Management.

Mishra, D. and R.S. Rao, 1992. 'Hunger in Kalahandi: Blinkered Understanding.' Economic and Political Weekly 27(24-25): 1245-6.

Mohanty, L. (ed.), 2010. 'Kalahandi District.' Orissa Review (Census Special) 67(5): 127-30. 
Mohapatra, G., 2012. 'Hunger and Coping Strategies Among Kondh Tribe in Kalahandi District, Odisha (Eastern India).' Transcience 3(2): 51-60.

Murthy, A.A. and Y. Giri Rao, 2006. Status Paper on Mining Leases in Orissa. Bhubaneswar: Vasundhara, Conservation and Livelihood Team.

Padel, F. and S. Das, 2010. Out of this Earth: East India Adivasis and the Aluminium Cartel. New Delhi: Orient BlackSwan.

Pati, B., 1999. 'Environment and Social History: Kalahandi, 1800-1950.' Environment and History 5(3): 345-59.

Pradhan, J., 1993. 'Drought in Kalahandi: The Real Story.' Economic and Political Weekly 28(22): 1084-8.

Roy Chowdhury, A. and K. Lahiri-Dutt, 2016. 'The Geophagous Peasants of Kalahandi: De-peasantisation and Artisanal Mining of Coloured Gemstones in India.' Extractive Industries and Society: 1-13. doi.org/ 10.1016/j.exis.2016.03.007

Sahoo, A.K., 2014. 'Gem Stones Deposits Found in Odisha River.' Deccan Chronicle, 13 July. Available at www.deccanchronicle.com/140713/ nation-current-affairs/article/gem-stones-deposits-found-odisha-river

Sahu, J.S., 2013. 'Kotwar Guarding Alexandrite Gemstone in Chhattisgarh!' Daily Pioneer, 21 April. Available at www.dailypioneer. $\mathrm{com} /$ state-editions/raipur/kotwar-guarding-alexandrite-gemstones-inchhattisgarh.html

Sahu, G.B., S. Madheswaran and D. Rajasekhar, 2004. 'Credit Constraints and Distress Sales in Rural India: Evidence from Kalahandi District, Orissa.' The Journal of Peasant Studies 31(2): 210-41. doi. org/10.1080/0306615042000224285

Sainath, P., 1996. Everybody Loves a Good Drought. New Delhi: Penguin.

Satapathy, R.K. and S. Goswami, 2006. 'Mineral Potential of Orissa State: A Kaleidoscopic Review.' Orissa Review (May): 1-14.

Siegel, S. and M.M. Veiga, 2009. 'Artisanal and Small-Scale Mining as an Extralegal Economy: De Soto and the Redefinition of "formalization".' Resources Policy 34: 51-6. doi.org/10.1016/j.resourpol.2008.02.001 
Slack, K., 2013. 'The Growing Battle Between Mining and Agriculture.' 29 March. International Network of Economics and Conflict, United States Institute of Peace. Viewed at inec.usip.org/blog/2013/mar/29/ growing-battle-between-mining-and-agriculture (site discontinued)

Tsing, A., 2009. 'Supply Chains and the Human Condition.' Rethinking Marxism: A Journal of Economics, Culture \& Society 21(2): 148-76.

Vagholikar, N., K.A. Moghe, and R. Dutta, 2003. Undermining India: Impacts of Mining on Ecologically Sensitive Areas. New Delhi: Kalpavriksh.

Van Bockstael, S. and K. Vlassenroot, 2008. 'Perspective and challenges.' In K. Vlassenroot and S. Van Bockstael (eds), Setting the Scene: Perspectives on Artisanal Diamond Mining, Amsterdam: Academia Press.

Verbrugge, B., 2015. 'The Economic Logic of Persistent Informality: Artisanal and Small Scale Mining in the Southern Philippines.' Development and Change 46(5): 1023-46. doi.org/10.1111/ dech.12189

Walsh, A., 2010. 'The Commodification of Fetishes: Telling the Difference Between Natural and Synthetic Sapphires.' American Ethnologist 37(1): 98-114. doi.org/10.1111/j.1548-1425.2010.01244.x

Yeboah, S., 2014. "Crops" or "Carats"? Interaction Between Gold Mining and Cocoa Production and the Livelihood Dilemma in Amansie Central District of Ghana.' 30 October, United Nations Research Institute for Social Development. Available at www.unrisd. org/UNRISD/website/newsview.nsf/(httpNews)/8ADA17334D5 C44E8C1257D81004558F0?OpenDocument 
This text is taken from Between the Plough and the Pick: Informal, artisanal and small-scale mining in the contemporary world, edited by Kuntala Lahiri-Dutt, published 2018 by ANU Press, The Australian National University, Canberra, Australia.

doi.org/10.22459/BPP.03.2018.04 